\title{
Effect of the Nitrate Reductase Genes (Nia) on the Quality of Different Lettuce Genotypes for Low Nitrate Content
}

\author{
K.N. Al-Redhaiman \\ Plant Production and Protection Department, College of Agriculture \\ and Veterinary Medicine, \\ Al Qassim University, Buraidah, P.O. Box 1486, Saudi Arabia \\ تأثير الجين المسؤول عن نشاط أنزيم اختزال النترات على جودة التراكيب الوراثية للخس من حيث خفض محتواها من النترات \\ خالد بن ناصر الرضيمان \\ الخلاصة: درست الاختلافات الوراثية بين سلالات الخس التي تنتمي إلى أربعة مجموعات هي (مجموعة الخس ذاتس التات الأوراق

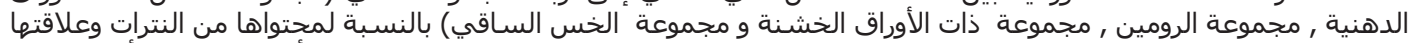

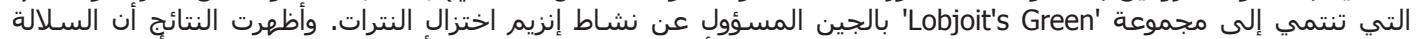 \\ الرومين كانت اقل تركيز للنترات في الأوراق (4877.7 'Augusta and Kennedy'

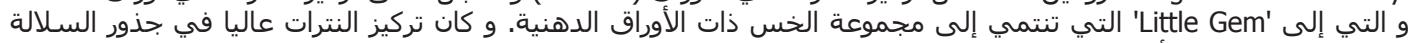

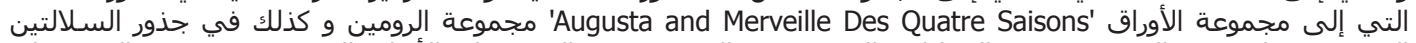

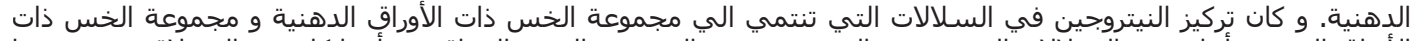

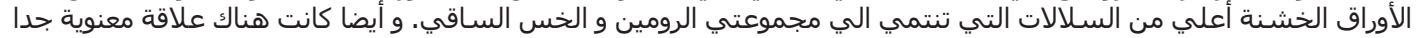

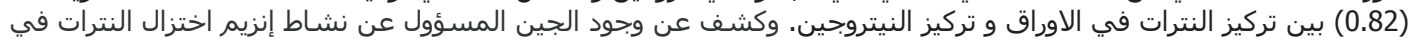 \\ بmbassador, Bath, Merveille des Quatre, Romain de Benicardo, Colona

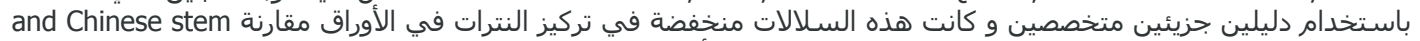

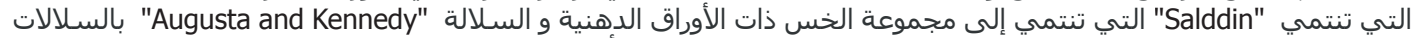

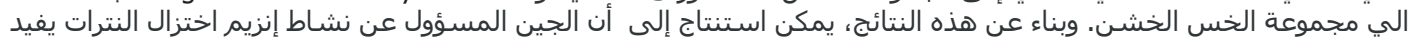 \\ في حصر التراكيب الوراثية للخس لخسناء لخفض محتواها من النترات المنات
}

ABSTRACT: Genotypic variation in nitrate concentrations of different lettuce genotypes belonging to four types (Butterhead, $\mathrm{Cos} /$ Romaine, Crisphead, and Stem lettuce) and its relationship to nitrate reductase genes (Nia) for low nitrate concentrations of leaves was investigated. The results showed that the Romaine genotype ' Lobjoit's Green' exhibited the lowest leaf nitrate concentration $(4877.7 \mathrm{mg} / \mathrm{kg}$ dry weight). The highest nitrate levels were recorded in the Butterhead genotypes 'Augusta and Kennedy'. Nitrate concentrations in the roots were significantly higher in the Romaine genotype ' Little Gem' and the Butterhead genotypes 'Augusta and Merveille Des Quatre Saisons' than the other lettuce genotypes. Total N concentrations were higher in the Butterhead and Crisphead genotypes than in the Romaine and Stem lettuce genotypes. A significant positive association $(\mathrm{r}=0.80, \mathrm{p}>0.01)$ was observed between leaf $\mathrm{NO}_{3}{ }^{-}$concentrations and total $\mathrm{N}$ concentrations. Moreover, gene-specific primer pairs for amplification of nitrate reductase revealed the presence of the gene (Nia) in Butterhead type (Ambassador, Bath, Merveille des QuatreSaisons), Cos/ Romaine type (Romain de Benicardo genotype), Crisphead type (Colona genotype), and Stem lettuce type (Chinese stem genotype). These genotypes showed lower leaf nitrate concentrations than the other Butterhead genotypes "Augusta and Kennedy" and Crisphead genotype "Salddin" which did not amplify with the Nia gene. Based on these results, it is concluded that the gene-specific primer pairs for amplification of nitrate reductase gene (Nia) might be useful in screening lettuce breeding material for low leaf nitrate content.

Keywords: Low nitrate concentrations, Lactuca sativa, PCR, Saudi Arabia.

\section{Introduction}

Concerns about high nitrate levels in vegetable production have led to the introduction of limits on nitrate concentrations in some salad crops (Anon.,
2001; Escobar-Gutierrez et al., 2002). Among vegetable crops, lettuce, along with spinach, is routinely ranked as one of the highest accumulators of nitrate $\mathrm{NO}_{3}^{-}$(Lorenz, 1978; Al-Redhaiman, 2000). 
Differences in the capacity to accumulate $\mathrm{NO}_{3}{ }^{-}$ among lettuce types (Crisphead, Butterhead, Romaine, Leaf) and their respective genotypes and cultivars are well documented (Reinink and Groenwold, 1988; Reinink, 1991). It has been shown that Crisphead cultivars contain higher $\mathrm{NO}_{3}{ }^{-}$than other lettuce types (Maynard et al., 1976). Escobar-Gutierrez et al. (2002) found that nitrate concentration showed not only great variability between cultivars in general, but also between the main lettuce types and between cultivars within the Butterhead type as well.

Genotypic and species differences in $\mathrm{NO}_{3}{ }^{-}$ accumulation may be related to differences in various physiological processes of nitrogen metabolism in plants, including uptake, reduction/assimilation, and translocation/partitioning (Al-Redhaiman, 1996). Cultivars can vary in efficiency of nitrogen assimilation, and accumulation of $\mathrm{NO}_{3}{ }^{-}$may be associated with a reduced capacity for $\mathrm{NO}_{3}{ }^{-}$reduction and a low nitrate reductase activity (NRA) (Goodman, 1979).

Nitrate reductase $(N R)$ is the first enzyme of the nitrate assimilation pathway in higher plants. It reduces the major plant nitrogen source, $\mathrm{NO}_{3}{ }^{-}$, into $\mathrm{NO}_{2}^{-}$, which is then further reduced to $\mathrm{NH}_{3}$ by $\mathrm{NO}_{2}$-reductase (Redinbaugh and Campbell, 1991; Pelsy and Caboche, 1996; Crawford, 1995). Arabidopsis thaliana has two NR genes, Nial and Nia2 (Cheng et al., 1988; Wilkinson and Crawford, 1993). Nia2 is responsible for $90 \%$ of the total NR activity in developing wild-type seedlings, whereas Nial accounts for the remaining $10 \%$ (Wilkinson and Crawford, 1991; Yu et al., 1997). The presence of the Nia cDNA in transgenic lettuce was confirmed by nitrate reductase $(N R)$ enzymatic assay and a reduction in the nitrate content of leaves (Curtis et al., 1999). The objectives of this study were to (1) study the genotypic variations in nitrate concentrations of different lettuce genotypes and (2) investigate the presence of the nitrate reductase gene (Nia) in lettuce genotypes and its relationship to low nitrate concentrations of leaves.

\section{Materials and Methods}

Seeds of eleven lettuce genotypes belonging to the types Butterhead (Ambassador, Augusta, Bath, Kennedy, and Merveille Des Quatre Saisons), Cos/ Romaine (Little Gem, Lobjoit's Green, and Romaine de Benicardo), Crisphead (Colona and Salddin), and
Stem lettuce (Chinese stem) were introduced from Horticulture Research International, Wellesbourne, Warwick CV35 9EF, UK. Seeds of each genotype were germinated in a mixture of peat moss and vermiculite $(1: 1 \mathrm{v} / \mathrm{v})$ at the greenhouse of the College of Agriculture and Veterinary Medicine, Al-Qassim University, Saudi Arabia.

The seedlings of each genotype were produced in mesh pots supported by the pot rims, in PVC channels approximately 14 days after germination. Plants were spaced at $19 \mathrm{~cm}$ within the rows. 25 liters of aerated nutrient solution were used for supplying two channels in which the nutrient solution was re-circulated. Four re-circulating hydroponics systems were used as replicates. The nutrient solution consisted of $\mathrm{Ca}$ $\left(\mathrm{NO}_{3}\right)_{2}, 0.575 ; \mathrm{KNO}_{3}, 0.331 ; \mathrm{Mg}\left(\mathrm{NO}_{3}\right)_{2} .7 \mathrm{H}_{2} \mathrm{O}$, $0.219 ; \mathrm{KH}_{2} \mathrm{PO}_{4}, 0.0828$ and $\mathrm{K}_{2} \mathrm{SO}_{4}, 0.1466(\mathrm{~g} / \mathrm{L})$. The micro nutrients were supplied to this solution as Fe-EDDHA 16; $\mathrm{MnSO}_{4} .7 \mathrm{H}_{2} \mathrm{O}, 2.44 ; \mathrm{H}_{3} \mathrm{BO}_{3}$, $0.68 ; \mathrm{ZnSO}_{4} .7 \mathrm{H}_{2} \mathrm{O}, \quad 0.176 ; \mathrm{CuSO}_{4} .5 \mathrm{H}_{2} \mathrm{O}, 0.156$ and $\left(\mathrm{NH}_{4}\right) 6 \mathrm{MO}_{7} \mathrm{O}_{24}, 0.148(\mathrm{mg} / \mathrm{L})$. The nutrient solution was changed weekly. The level of solution $\mathrm{NO}_{3}{ }^{-}$was monitored daily, and was replenished back to its original concentration with $\mathrm{KNO}_{3}$ when the concentration of $\mathrm{NO}_{3}{ }^{-}$fell below one-half of its initial level. The EC of nutrient solution was about $2.5 \mathrm{dS} / \mathrm{m}$. The $\mathrm{pH}$ of the solution was maintained between 5.8 and 6.2 by adjustments with nitric and phosphoric acids $(3: 1 \mathrm{v} / \mathrm{v})$.

After 75 days of growth, three plants of each genotype were randomly chosen from each replicate. The samples of leaves and roots were oven dried at $70^{\circ} \mathrm{C}$ then ground in a blender and stored in glass vials for $\mathrm{NO}_{3}{ }^{-}$and total $\mathrm{N}$ determinations. Nitrate contents of leaves and roots of each genotype were determined by nitration of salicylic acid (Cataldo et al., 1975) and the results expressed as $\mathrm{mg} \mathrm{NO}_{3}^{-}$, per kg dry weight. Tissue total $\mathrm{N}$ was determined using a modified microKjeldahl digestion procedure (Nelson and Summers, 1980).

Total genomic DNA of lettuce genotypes was extracted using the cetyltrimethyl-ammonium bromide (CTAB) method described by Hoisington et al. (1994). Each sample $(0.5 \mathrm{~g})$ of leaf tissue was transferred to a tube containing $10 \mathrm{ml}$ of extraction buffer $(1.5$ $\mathrm{M} \mathrm{NaCl}, 100 \mathrm{mM}$ Tris- $\mathrm{HCl} \mathrm{pH}$ 8, 20 mM EDTA, 1\% CTAB). The samples were incubated for 2 hours at $65^{\circ} \mathrm{C}$ with occasional mixing. Following incubation, 5 $\mathrm{ml}$ of chloroform/isoamylalcohol (24:1) was added to 


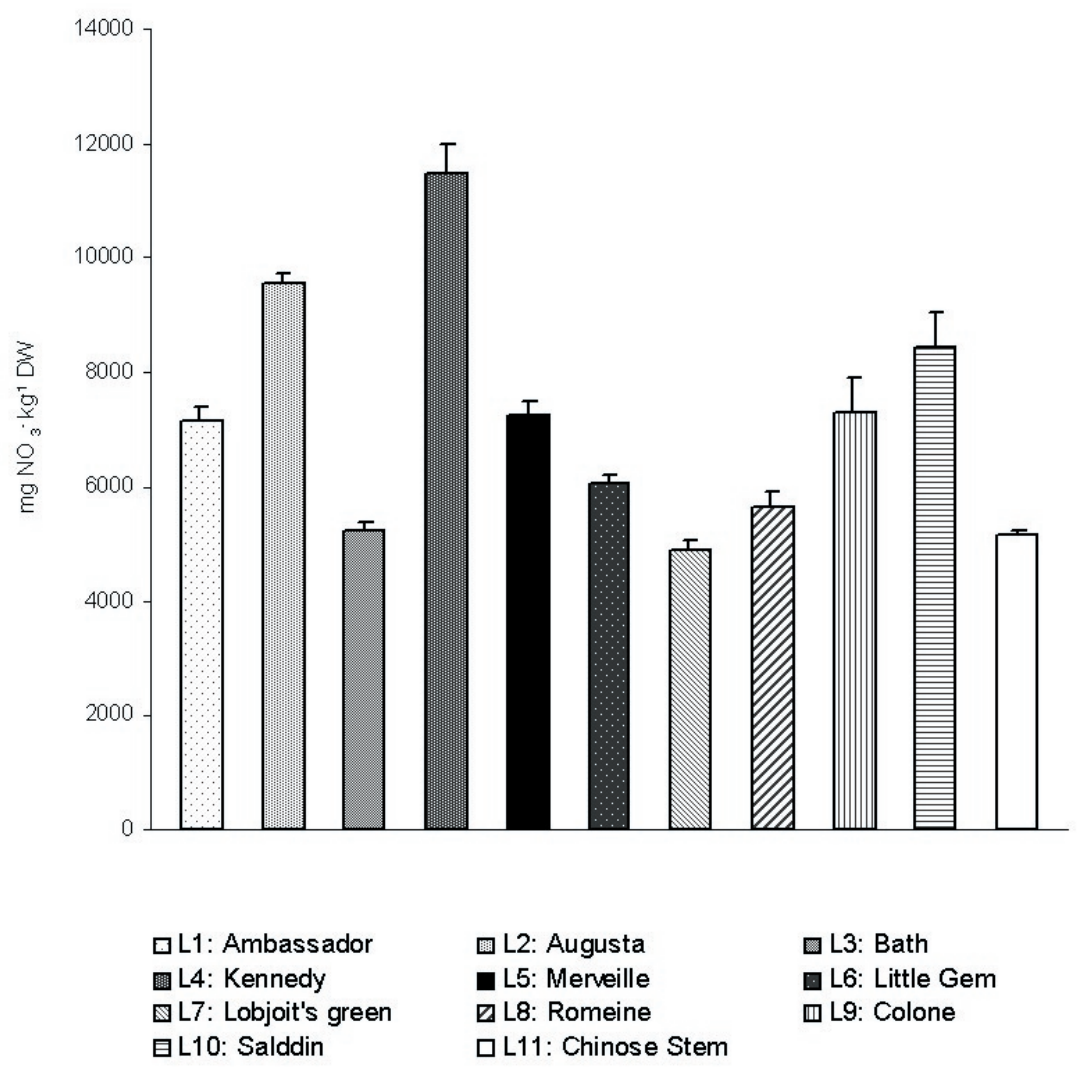

Figure 1: NO3- concentrations in leaves of eleven lettuce genotypes. Vertical bars show standard errors of four replicates.

the tubes, mixed, and centrifuged at $2600 \mathrm{~g}$ for $10 \mathrm{~min}$. The aqueous phase was removed to a fresh tube and an equal volume of ice-cold isopropanol was added, followed by centrifugation as above to precipitate the DNA. The pellet was washed in $70 \%$ ethanol and dissolved in TE buffer (10mM Tris- $\mathrm{HCl}$, pH8.0, $0.1 \mathrm{mM}$ EDTA).

Gene-specific primer pairs for amplification of the nitrate reductase gene (Nia) were as follows: forward primer, 5'-GGTAGGCGATTGGCTAACA TTGTCTGC-3'; and reverse primer 5'-GAGACAC CAACAGTCTTTCCTCTGCG-3' (Sherameti et al., 2002). Amplification was carried out in $25 \mu 1$ reaction volumes, containing $1 \mathrm{X}$ Taq polymerase buffer (50 $\mathrm{mM} \mathrm{KCl}, 10 \mathrm{mM}$ Tris, $\mathrm{pH} 7.5,1.5 \mathrm{mM} \mathrm{MgCl}$ ) and 1 unit of Taq polymerase (Pharmacia Biotech, Germany) supplemented with $0.01 \%$ gelatin, 0.2 $\mathrm{mM}$ of each dNTPs (Pharmacia Biotech, Germany), 25 pmol primer, and $50 \mathrm{ng}$ of total genomic DNA. Amplification was performed in a thermal cycler
(Thermolyne Amplitron) programmed for 1 cycle of $30 \mathrm{~s}$ at $94^{\circ} \mathrm{C}$; and 40 cycles of $1 \mathrm{~min}$ at $94^{\circ} \mathrm{C}, 1 \mathrm{~min}$ at $63^{\circ} \mathrm{C}$, and $1 \mathrm{~min}$ at $72^{\circ} \mathrm{C}$; followed by $5 \mathrm{~min}$ at $72^{\circ} \mathrm{C}$. An aliquot of $10 \mu \mathrm{l}$ from each reaction product was resolved by electrophoresis on $1.5 \%$ agarose gel in $1 \mathrm{X}$ TAE buffer, stained with ethidium bromide, and visualized with UV light.

Data were statistically analyzed by using a randomized complete block design with four replicates through Student-Keul's Test according to Sendecor and Cochran (1980). The least significant differences were used to compare means at the 5\% level. Linear association between total $\mathrm{N}$ of plant tissue and leaf nitrate concentrations was determined.

\section{Results and Discussion}

Leaf nitrate concentrations showed significant differences $(\mathrm{P}<0.05)$ among lettuce genotypes (Fig. 1). The Romaine genotype 'Lobjoit's Green' exhibited the lowest leaf nitrate concentration $(4877.7 \mathrm{mg} / \mathrm{kg}$ 


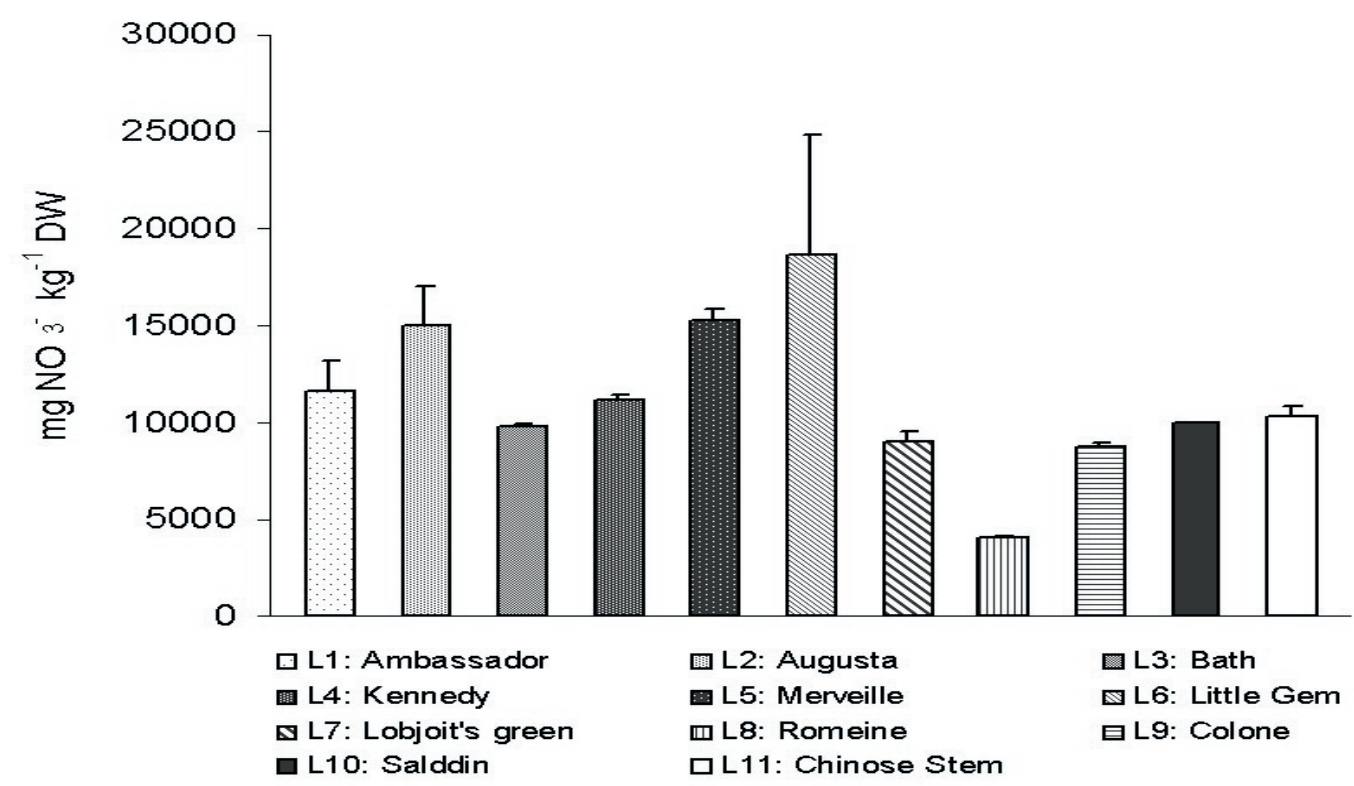

Figure 2: NO3- concentrations in roots of eleven lettuce genotypes. Vertical bars show standard errors of four replicates.

dry weight). The Stem genotype 'Chinese stem', the Buterhead genotype 'Bath', and the Romaine genotypes 'Romaine de Benicardo' and 'Little Gem' also showed lower nitrate concentrations than other genotypes. The highest nitrate levels were recorded in the Butterhead genotypes 'Augusta and Kennedy'. It was recognized that lettuce genotypes can differ in nitrate accumulation (Behr and Wiebe, 1988; Reinink, 1992; Belligno et al., 1996). Regarding within Butterhead genotypes, 'Bath' showed a lower nitrate concentration than the other Butterhead genotypes. Therefore, for nitrate concentration a high variability was found, not only among genotypes in general, but also between the lettuce types, and among genotypes within the Butterhead group (Escobar-Gutierrez et al., 2002).

In the roots of lettuce genotypes, the Romaine genotype 'Romaine de Benicardo' exhibited the lowest nitrate concentration (4000 mg/kg dry weight) (Fig. 2). Nitrate concentration in the roots was significantly higher in the Romaine genotype 'Little Gem' and the Butterhead genotypes 'Augusta and Merveille Des Quatre Saisons' than other lettuce genotypes. It may be noted that the Romaine genotype 'Little Gem' showed a low nitrate concentration in the leaves. This might indicate that the Romaine genotype 'Little Gem' can store a large portion of absorbed material in the roots thus translocating less $\mathrm{NO}_{3}{ }^{-}$to leaves. Al-Redhaiman (2000) reported that lettuce genotypes can accumulate $\mathrm{NO}_{3}$ - to different levels due to their differential translocation or partitioning characteristics.

Significant differences $(\mathrm{P}<0.05)$ in total nitrogen concentrations as a percentage among lettuce genotypes were found (Fig. 3). In general, total $\mathrm{N}$ concentrations were higher in the Butterhead and Crisphead genotypes than in the Romaine and Stem lettuce genotypes. This confirms the findings of AlRedhaiman (1996) that total N concentrations were higher in the Butterhead cultivars than in the Romaine type.

Correlation analysis was performed for the overall dataset to establish whether there was a significant relationship between total $\mathrm{N}$ concentrations of plant tissues and leaf nitrate concentrations. A significant ( $\mathrm{p}$ $<0.01)$ positive association $(\mathrm{r}=0.80, \mathrm{p}<0.01)$ was observed between leaf $\mathrm{NO}_{3}{ }^{-}$concentrations and total $\mathrm{N}$ concentrations. Genotypes such as Lobjoit's Green and Chinese stem were characterized by the lowest genotypes of leaf nitrate concentrations and total $\mathrm{N}$ concentrations. On the other hand, the Butterhead genotypes 'Augusta and Kennedy' were characterized by the highest genotypes of leaf nitrate concentrations and total $\mathrm{N}$ concentrations. A positive and significant correlation between leaf $\mathrm{NO}_{3}{ }^{-}$concentrations and total 


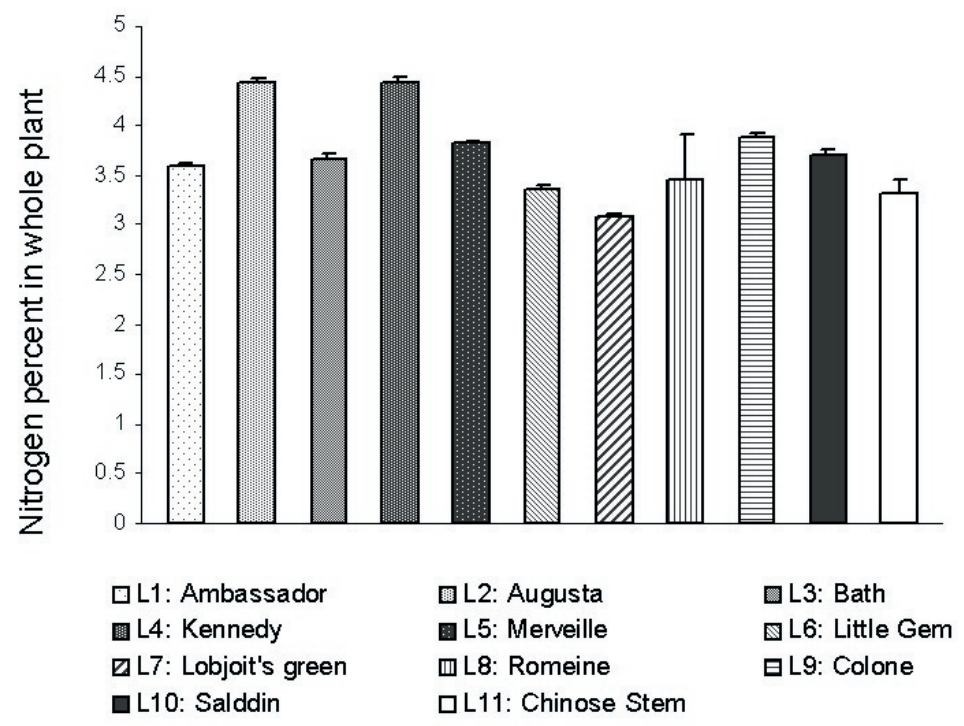

Figure 3. Nitrogen percent in plant tissues of eleven lettuce genotypes. Vertical bars show standard errors of four replicates.

$\mathrm{N}$ concentrations was also reported by Al-Redhaiman (1996) and Gent (2003). In general, total $\mathrm{N}$ in the plants results from accumulated $\mathrm{N}$ uptake. Therefore, variation in leaf nitrate concentrations in lettuce genotypes may be attributed to differences in nitrate uptake (Behr and Wiebe, 1992; Al-Redhaiman, 2000).

The nitrate reductase gene (Nia), which is responsible for the nitrate reductase activity, was amplified from Butterhead type (Ambassador, Bath and Merveille des Quatre Saisons genotypes), Cos/ Romaine type (Romain de Benicardo genotype), Crisphead type (Colona genotype), and Stem lettuce type (Chinese stem genotype). The amplification of

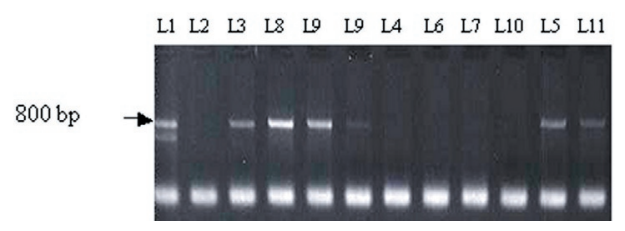

Figure 4. Agarose gel of amplified nitrate reductase gene (Nia) from eleven lettuce genotypes (left to right) Ambassador (L1), Augusta (L2), Bath (L3), Romaine (L8), Colona (L9), Kennedy (L4), Little Gem (L6), Lobjoit's Green (L7), Saladin (L10), Merveille (L5), and Chinese stem (L11). the Nia gene of these genotypes yielded one fragment of approximately $800 \mathrm{bp}$ (Fig. 4). On the other hand, the Nia gene was not amplified in PCR from other genotypes. It was interesting to note that the Butterhead genotypes 'Ambassador, Bath and Merveille des Quatre Saisons' had the nitrate reductase gene (Nia) and showed low leaf nitrate concentrations. However, the other Butterhead genotypes 'Augusta and Kennedy' exhibited the highest leaf nitrate concentrations and did not amplify with the Nia gene. Moreover, the Romaine genotype 'Romaine de Benicardo' was amplified with the Nia gene and showed low nitrate concentrations in the leaves and roots. Therefore, the low nitrate content in lettuce might be due to the nitrate reductase gene (Nia). Al-Redhaiman (1996) suggested that genotypic differences in $\mathrm{NO}_{3}^{-}$accumulation in lettuce are not exclusively the result of cultivar differences in $\mathrm{NO}_{3}{ }^{-}$uptake and reduction, but may also involve other factors related to $\mathrm{NO}_{3}{ }^{-}$metabolism, such as nitrate reductase activity. The total nitrate reductase activity is regulated comparably to the expression of the nitrate reductase genes (Sharameti et al., 2002). Curtis et al. (1999) concluded that the presence of the nitrate reductase gene (Nia) in transgenic lettuce was confirmed by nitrate reductase enzymatic assay, a reduction in the nitrate content of leaves and by Southern hybridization. 
The work presented in this paper illustrates that sensitive specific PCR assays represents a valuable and a new tool for screening lettuce breeding material for low nitrate content which will be a major objective in lettuce breeding programs to limit nitrate concentration in salad crops. This could be of great importance since high nitrate concentration can be toxic and may cause illness or even death in humans.

\section{References}

Al-Redhaiman, K.N. 1996. Nitrate accumulation in hydroponically-grown lettuce cultivars and relationship to nitrogen supply. Ph.D. Dissertation, University of Illinois, Urbana-Champagn.

Al-Redhaiman, K.N. 2000. Nitrate accumulation in plants and hazards to man and livestock health: A review. Journal of King Saud University 12: 143-156.

Anonymous. 2001. Commission regulation (EC) No. 466/2001 of 8 March 2001 setting maximum levels for certain contaminants in foodstuffs (Text with EEA relevance). Official Journal of the European Communities, L 77, 16 March 2001, 1-13.

Behr, U. and H.J. Wiebe. 1988. Relations between nitrate content and other osmotica in the cell sap of lettuce cultivars. Gartenbauwissenschaft 53: 206-210.

Behr, U. and H.J. Wiebe. 1992. Relation between photosynthesis and nitrate content of lettuce cultivars. Scientia Horticulturae 49:175-179.

Belligno, A., G. Fisichella, M. Tropea, G. Sambuco and G. Muratore. 1996. Effects of different nitrogenous fertilizers on nitrate content of lettuce plants. 1 . Comparison of a new slow-release fertilizer with traditional fertilizers. Agrochimica 40: 85-93.

Cataldo, P.A., M. Harnon, L.E. Schrader and V.L. Youngs. 1975. Rapid colorimetric determination of nitrate in plant tissue by nitration of salicylic acid. Community Soil Sciences and Plant Analogy 6:71-80.

Cheng, C.L., J. Dewdney, H.G. Nam, B.G.W. DenBoer and H.M. Goodman. 1988. A new locus (Nia1) in Arabidopsis thaliana encoding nitrate reductase. European Molecular Biology Organization Journal 7:3309-3314.

Crawford, N.M. 1995. Nitrate: nutrient and signal for plant growth. Plant Cell 7:859-868.
Curtis, I.S., J.B. Power, A.M.M. de Laat, M. Caboche and M.R. Davey. 1999. Expression of a chimeric nitrate reductase gene in transgenic lettuce reduces nitrate in leaves. Plant Cell Reports 18:889-896.

Escobar-Gutierrez, A.J., I.G. Burns, A. Lee and R.N. Edmondson. 2002. Screening lettuce cultivars for low nitrate content during summer and winter production. Journal of Horticultural Science and Biotechnology 77:232-237.

Gent, M.P.N. 2003. Solution electrical conductivity and ratio of nitrate to other nutrients affect accumulation of nitrate in hydroponic lettuce. Horticultural Science 38:222-227.

Goodman, P.J. 1979. Genetic control of inorganic nitrogen assimilation of crop plants. In: Nitrogen Assimilation of Plants, E.J. Hewitt and C.V. Cutting (Editors), 165-176. Academic Press, New York.

Hoisington, D.A., M.M. Khairallah and D. Gonzalesde-Leon. 1994. Laboratory Protocols. CIMMYT Applied Molecular Genetics Laboratory, Mexico, DF.

Lorenz, O.A. 1978. Potential nitrate levels in edible plant parts. In: Nitrogen in the Environment, D.R. Nielsen and J.G. MacDonald (Editors), 201-219, Vol 2. Acadamic Press, New York.

Maynard, D.N., A.V. Barker, P.L. Minotti and N.H. Peck. 1976. Nitrate accumulation in vegetables. Advanced Agronomy 28:71-118.

Nelson, D.W. and L.E. Summers. 1980. Total nitrogen analysis of soil and plant tissues. Journal of the Association of Official Analytical Chemists 63: 770-778.

Pelsy, F. and M. Caboche. 1992. Molecular genetics of nitrate reductase in higher plants. Advanced Genetics 30:1-40.

Redinbaugh, M. G. and W.H. Campbell. 1991. Higher plant responses to environmental nitrate. Plant Physiology 82:640-650.

Reinink, K. 1991. Genotype by environment interaction for nitrate concentration in lettuce. Plant Breeding 107:39-49.

Reinink, K. 1992. Genetics of nitrate content in lettuce. 2. Components of variance. Euphytica 60:61-74.

Reinink, K. and R. Groenwold. 1988. The inheritance of nitrate content in lettuce (Lactuca sativa L.). Euphytica 36:733-744.

Sherameti, I., S.K. Sopory, A. Trebicka, T. Pfannschmidt and R. Delmuller. 2002. Photosynthetic electron 
transport determines nitrate reductase gene Wilkinson, J.Q. and N.M. Crawford. 1992. expression and activity in higher plants. Journal of Identification and characterization of a chlorate Biological Chemistry 277:46594-46600.

Snedecor, G.W. and W.G. Cochran. 1980. Statistical Methods. Sixth Edition, Iowa State University Press, Ames, Iowa. resistant mutant of Arabidopsis with mutations in both Nial and Nia2 nitrate reductase structural genes. Molecular and General Genetics 239: 289-297.

Wilkinson, J.Q. and N.M. Crawford. 1991. Identification of the Arabidopsis CHL3 gene as the nitrate reductase structural gene Nia2. Plant Cell $3: 461-471$.

Yu, X., S. Sukumaran and L. Marton. 1998. Differential expression of the Arabidopsis Nial and Nia2 genes. Plant Physiology 116:1091-1096.

Received: January 2005

Accepted: April 2005 